\title{
Loss of Morphology in Alorese (Austronesian): Simplification in Adult Language Contact
}

\author{
Francesca R. Moro \\ Leiden University \\ f.r.moro@hum.leidenuniv.nl
}

\begin{abstract}
This paper discusses historical and ongoing morphological simplification in Alorese, an Austronesian language spoken in eastern Indonesia. From comparative evidence, it is clear that Alorese lost almost all of its morphology over several hundred years as a consequence of language contact (Klamer, 2012, to appear). By providing both linguistic and cultural-historical evidence, this paper shows that Alorese has historically undergone morphological simplification as a result of second language (L2) learning. The first part of the paper presents a case study comparing the use of subject agreement prefixes in Alorese L1 speakers $(n=6)$ and Alorese L2 speakers $(n=12)$. The results show that L2 speakers deviate from the native norm, and tend to use one prefix as default agreement. The variation found among L2 speakers reveals an ongoing change possibly leading to the restructuring of the Alorese agreement system. The second part of the paper applies models of linguistic change (Kusters, 2003; Trudgill, 2011) to the Alorese community and shows that Alorese has been, and still is, spoken in a community with a large number of L2 speakers, where morphological simplification is expected to occur.
\end{abstract}

\section{Keywords}

austronesian - simplification - L2 speakers - subject agreement - morphology 


\section{Introduction ${ }^{1}$}

This paper discusses historical and ongoing morphological simplification in Alorese, a language spoken in a small-scale, pre-industrialized, pre-literate society in eastern Indonesia. From comparative evidence, it is clear that Alorese lost almost all of its nominal and verbal morphology in a few hundred years as a consequence of language contact (Klamer, 2012, to appear). Following a bottom up approach, this paper uses synchronic language data from Alorese second language (L2) speakers to reconstruct the diachronic process of morphological simplification. These L2 speakers acquired Alorese during early adulthood in the context of mixed marriages or shared work practices, and although some have reached ultimate attainment, their acquisition is imperfect. The study of morphological variation among these L2 speakers reveals a possible language change in progress leading to the restructuring of the verbal agreement system. Since contact-induced change starts out as contact-induced variation (see among others Schendl, 2001: 3), I hypothesize that the variation found among L2 speakers may become a fully-fledged change.

By studying morphological variation in Alorese L2 speakers, this study provides evidence that adult second-language learning typically leads to simplification (Kusters, 2003; Trudgill, 2011; Ross, 2013). Evidence from synchronic language data is supported by demographic, social and cultural data surveyed in the Alorese speaking villages. In doing so, this study is an answer to a call by Ross (2013: 37) for more synchronically informed variationist studies "if we are to understand how contact-induced change takes place in small scale societies". Furthermore, the study of agreement prefixes presented in this paper gives an insight into restructuring and the matter of morphological stability in contact situations involving untutored L2 learning.

Alorese is a language spoken in the Alor archipelago, which belongs to the Province of Nusa Tenggara Timur, eastern Indonesia. It has approximately 25,000 L1 speakers (Simons and Fennig, 2017), and it is spoken in three villages on Alor island (Alor Besar, Alor Kecil and Dulolong), in a number of villages on Pantar (the most important being Munaseli, Pandai and Baranusa), and on two small islands in the Alor-Pantar strait (see Fig 1). Alorese is the only indigenous

1 This research was supported by the VICI research project 'Reconstructing the past through languages of the present: the Lesser Sunda Islands' at Leiden University, funded by the Netherlands Organization for Scientific Research, Nwo project number 277-70-012. I wish to thank Marian Klamer, Owen Edwards, Hanna Fricke and Henning Schreiber two anonymous reviewers for their critical comments on an earlier version of this paper. All errors remain mine. 


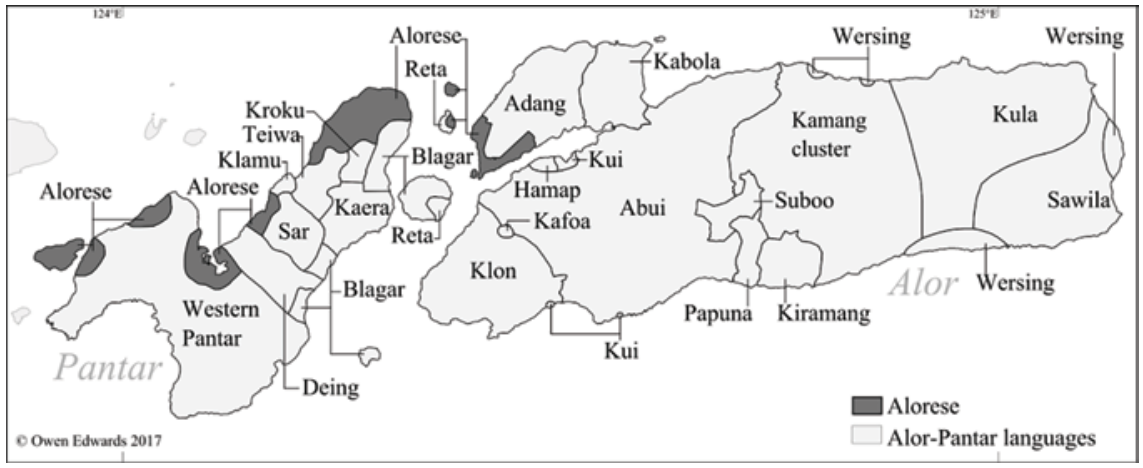

FIGURE 1 Alorese as spoken on Alor and Pantar, and the neighboring Papuan languages.

Austronesian language on Alor and Pantar, which are predominantly Papuan speaking. ${ }^{2}$

On the peninsula Alor, Alorese is spoken in close proximity to Adang; in the northern part of Pantar, it is spoken alongside Blagar, Kroku, Teiwa, Klamu (also known as Nedebang) and Kaera, and in the central part of Pantar next to Sar, and West Pantar (Fig. 1). These Papuan languages all belong to a single language family, the Timor-Alor-Pantar family (Holton et al., 2012). Generally speaking, villages are either predominantly Alorese speaking or Papuan speaking. However, the villages are very close to each other and often two Alorese speaking villages are separated by at least one non-Alorese speaking village(s). Furthermore, there are also some mixed communities. For instance, on Alor, the village Aimoli is predominantly Adang speaking, but the hamlet Wahing is inhabited by Alorese speakers. One reviewer reports that on Pantar there are communities where Nedebang speakers and Alorese speakers live alongside one another.

Genealogically, Alorese is a member of the Flores-Lembata subgroup of Malayo-Polynesian languages, which also includes Sika, Kedang and Lamaholot (LH) (Fernandez, 1996). Within the Flores-Lembata languages, the closest genealogical relative of Alorese is Lamaholot, a language that spreads out as a cluster of dialects in the eastern part of Flores and its offshore islands (Fig. 2). Cultural and linguistic evidence indicate that the Alorese are descendants of

2 The term "Papuan" is used here as a synonym of "non-Austronesian," indicating that Alorese and the neighboring languages are not genealogically related. In the literature, "Papuan" is used to refer to a group of over 700 non-Austronesian languages spoken on Timor, Halmahera and New Guinea, not all of which are demonstrably related to each other (Foley, 1986). 


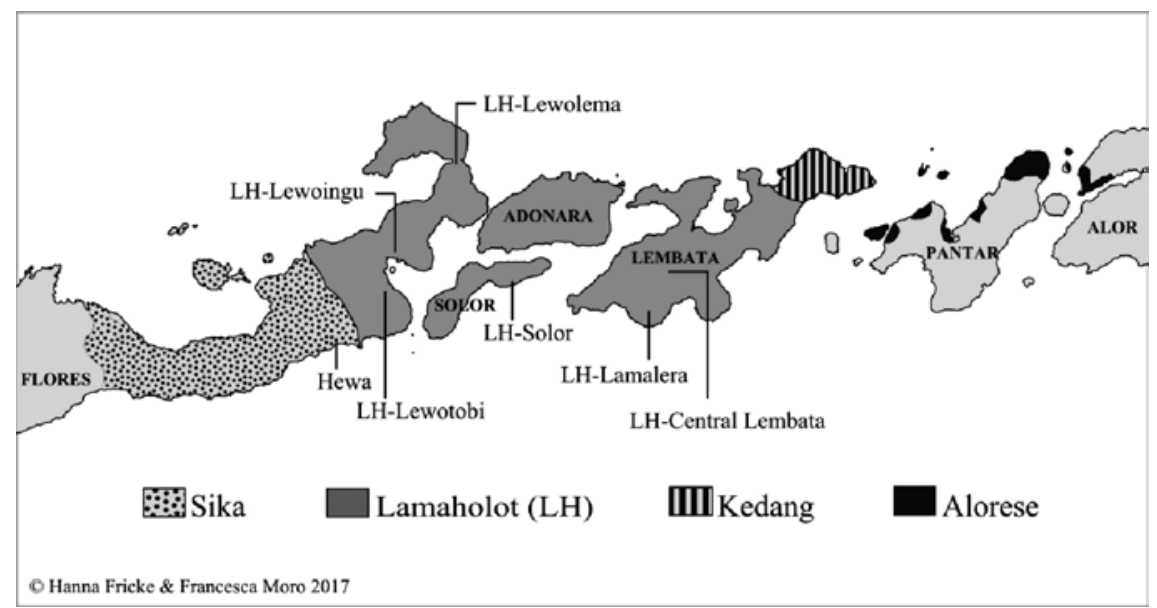

FIGURE 2 Alorese in its regional context

groups migrating eastwards from the Lamaholot speaking area (Stokhof, 1975: 8; Klamer, 2011: 8-15; Wellfelt, 2016: 248-249). These groups settled on Pantar at the beginning the $14^{\text {th }}$ century and afterwards, in the $16^{\text {th }}$ century, a group of Alorese speakers moved to the peninsula Alor (see section 5.1). Alorese is reported to have been used as a lingua franca in the area of the Alor-Pantar strait before Indonesian was introduced in the 196o's (Stokhof, 1975: 8; DuBois, 1944: 16).

By comparing Alorese to Lamaholot, Klamer (2012, to appear) is able to show that the inflectional and derivational morphology once present in ProtoLamaholot, the shared ancestor of Alorese and Lamaholot, was completely lost in Alorese some time after it split from Lamaholot in the $14^{\text {th }}$ century.

The first evidence comes from inflectional morphology. Lamaholot (the Lewoingu variety) marks subject agreement on verbs (Table 1 ). There are two different subject paradigms: a set of prefixes marking transitive subjects (A), and a set of suffixes marking intransitive subjects $(\mathrm{S})$, as well as nominal agreement on adjectives and numerals (Klamer, 2012, to appear). These affixes were inherited from Proto-Lamaholot, as they are also found in other Lamaholot varieties (Nagaya, 2011: 103), as well as in Kedang (Samely, 1991: 70) and Hewa, a variety of Sika (Fricke, 2014: 29).

In Lewoingu Lamaholot, the A prefixes are obligatory for about 20 verbs (Nishiyama and Kelen, 2007: 32), while the S suffixes are optional but occur on a broader number of verbs. The condition for the use of the A prefixes is phonological: only vowel initial verbs can take these prefixes (Nishiyama and Kelen, 2007: 98). The same holds for Hewa, where these prefixes only occur on 
TABLE 1 Subject affixes in Lamaholot and Alorese

\begin{tabular}{lllll}
\hline & \multicolumn{2}{c}{ Lamaholot (Lewoingu) } & & Alorese \\
\cline { 2 - 3 } \cline { 5 - 5 } & A prefix (on 2o verbs) & S Suffix & & A prefix (on 8 verbs) \\
& & & & \\
\hline 1SG & $k-$ & $-k a n$ & & $k-$ \\
2SG & $m-$ & $-k o,-n o$ & & $m-$ \\
3SG & $n-$ & $-n a,-n \partial n$ & $n-$ \\
1 PL.EXCL & $m-$ & $-k a n$ & & $m-$ \\
1 PL.INCL & $t-$ & $-t e$ & \\
2PL & $m-$ & $-k e /-n e$ & \\
3PL & $r-$ & $-k a$ & \\
& & & $r-$ \\
\hline
\end{tabular}

vowel initial verbs (Fricke, 2014: 29, but cf. Nagaya, 2011:105-106). In Lewoingu Lamaholot and in Lewotobi Lamaholot, some verbs hosting the A prefixes can appear with the default agreement prefix $n$ - ' $3 \mathrm{SG}^{\mathrm{S}}$ ' when they function as adverbial expressions or as prepositions (Nishiyama and Kelen, 2007: 103; Nagaya, 2011: 290). ${ }^{3}$ Additionally, in Lewoingu Lamaholot, some adverbials and numerals can occur with the default agreement suffix $-k a$ ' 3 PL' (Nishiyama and Kelen, 2007: 105). ${ }^{4}$ Thus, there is evidence that some forms have fossilized and have acquired a more grammatical meaning.

Alorese has almost entirely lost the subject agreement affixes: it has entirely lost the $S$ suffixes, and the A prefixes are used only on about eight vowel initial verbs (for a description of the Alorese A prefixes, see section 2). Table 1 contrasts the agreement paradigms of Lewoingu Lamaholot and of Alorese.

The second evidence contrasts the set of derivational affixes found in Lamaholot to the total absence of any derivational affix in Alorese (Klamer, 2012: 89-90, to appear). Lewoingu Lamaholot has seven derivational affixes, which are inherited from Proto-Austronesianor from Proto-Malayo-Polynesian. As shown in Table 2, Alorese has lost all these derivational affixes; the only productive derivational process is reduplication.

3 One example is the verb -o'on 'accompany, be with', which in the form no'on functions as a conjunction meaning 'and, with'. When used in this way, the verb does not agree with the subject, but hosts the default $3 \mathrm{Sg} n$ - agreement.

4 One example is the adverbial aya'ka 'too-3PL' in the sentence mo pana bera aya'-ka (you walk fast too-3PL 'you walk too fast'). 
TABLE 2 Derivational affixes in Lamaholot and Alorese (adapted from Table 2 in Klamer, to appear)

\begin{tabular}{|c|c|c|c|}
\hline & & $\begin{array}{l}\text { Lamaholot } \\
\text { (Lewoingu) }\end{array}$ & Alorese \\
\hline- & $\begin{array}{l}\text { Consonant replacement: it derives nouns } \\
\text { denoting result, location, or tool }\end{array}$ & yes & no \\
\hline- & $\begin{array}{l}\text { Prefix } b e(C)-: \text { it derives nouns denoting actor, } \\
\text { action, or tool, and stative verbs }\end{array}$ & yes & no \\
\hline- & $\begin{array}{l}\text { Prefix } р{ }^{-} \text {: it derives verbs meaning 'to be like } \\
\text { the base N', and actor/activity nouns }\end{array}$ & yes & no \\
\hline- & Prefix $k \partial^{-}:$it derives nouns denoting result, or tool & yes & no \\
\hline- & $\begin{array}{l}\text { Infix -an- : it derives nouns denoting an actor, action, } \\
\text { state, result, or tool }\end{array}$ & yes & no \\
\hline- & $\begin{array}{l}\text { Prefix } m \partial n^{-} \text {: it derives stative verbs, or nouns (actor, } \\
\text { action, result) }\end{array}$ & yes & no \\
\hline- & Prefix $g \partial(C)-:$ it derives action, actor or result noun & yes & no \\
\hline- & $\begin{array}{l}\text { Reduplication: it indicates iterative or intensive activity } \\
\text { (on verbs); it denotes plural diversity (on nouns) }\end{array}$ & yes & yes \\
\hline
\end{tabular}

On the basis of this evidence, Klamer (2012: 72, to appear) concludes that Proto-Lamaholot had a rich set of morphology, and hypothesizes that Alorese lost almost all its morphology as a consequence of going through a stage where adult speakers acquired it as a second language.

This paper provides linguistic and cultural-historical evidence from the Alorese community on Alor supporting this stage of second language learning proposed by Klamer (2012, to appear). In the first part of this paper, I focus on the last vestige of Alorese productive morphology, namely subject agreement prefixes on vowel initial verbs (see Table 1 ). This domain of investigation is particularly suitable because (i) it is the only inflectional morphology left in Alorese, and (ii) inflectional morphology is vulnerable in terms of linguistic stability in language contact situations, such as in adult L2 learning (see section 2). To investigate whether subject agreement is eroding, I compare the production of subject prefixes on vowel initial verbs in a group of Alorese L1 speakers $(\mathrm{n}=6)$ and a group of Alorese L2 speakers $(\mathrm{n}=12)$.

In the second part of this paper, I apply the models of linguistic change proposed by Kusters (2003) and Trudgill (2011) to the history of the Alorese 
community to investigate which socio-historical patterns of multilingualism led to the restructuring of Alorese. Cultural, historical and demographic evidence (Wellfelt, 2016; my fieldwork notes) shows that Alorese has been, and still is, spoken in a community with a large amount of L2 speakers, where morphological simplification is expected to occur (see section 4 and section 5 ).

The structure of the paper is as follows. Section 2 describes the Alorese subject agreement prefixes. Section 3 presents the case study on subject agreement morphology by comparing the use of prefixes in Alorese L1 and L2 speakers. Section 4 illustrates models of linguistic change, while Section 5 presents past (section 5.1) and present (section 5.2) cultural and demographic data on the Alorese community. Section 6 brings together the findings of the previous sections and explains why and how Alorese lost its morphology.

\section{$2 \quad$ Alorese Subject Agreement Prefixes}

Alorese has a set of prefixes marking the A subject in a small set of highfrequency verbs. The verbs that can take the A prefixes are:-ala 'to pass', -ang 'to eat', - ang 'to use, to make', -ate 'to carry, -ei 'to go', -enung 'to drink', -oing 'to know', -ong 'to be with'. All these verbs are clearly transitive except - ei 'to go'. As for Lamaholot, the condition for the use of the subject agreement prefixes is probably phonological, as only vowel-initial verbs can host the subject prefixes. The prefixes can be used in combination with free subject pronouns. An illustration is given in (1) with the verb 'to drink', 'to carry' and the suppletive forms of the verb 'to eat'.

\begin{tabular}{|c|c|c|c|c|}
\hline $1 \mathrm{SG}$ & $\begin{array}{l}\text { pronoun } \\
\text { (go) }\end{array}$ & $\begin{array}{l}\text {-ate 'to carry' } \\
k \text {-ate }\end{array}$ & $\begin{array}{l}\text {-enung 'to drink' } \\
\text { k-enung }\end{array}$ & $\begin{array}{l}\text {-ang 'to eat' } \\
k \text {-ang }\end{array}$ \\
\hline $2 S G$ & (mo) & $m$-ate & m-enung & g-ong \\
\hline $3 S G$ & (no) & n-ate & n-enung & $g$-ang \\
\hline 1 PL.EXCL & (kame) & $m$-ate & m-enung & g-eng \\
\hline 1 PL.INCL & (ite) & t-ate & t-enung & $t$-aka \\
\hline $2 \mathrm{PL}$ & $(\mathrm{mi})$ & $m$-ate & m-enung & g-eng \\
\hline $3 \mathrm{PL}$ & $(\mathrm{fe})$ & r-ate & r-enung & $r-a k a$ \\
\hline
\end{tabular}

Note that the inflectional paradigm contains three $m$ - homophonous prefixes: the 2SG, 1PL.EXCL and $2 \mathrm{PL}$. These prefixes are not homophonous due to morphological simplification, but because they reflect Proto-Malayo-Polynesian $\mathrm{CV}$ forms that each began with *m- and lost their vowels on account of the vowel-initial stems with which they occur. 


\section{Case Study: Agreement Morphology in Alorese L1 and L2 Speakers}

The present case study investigates subject agreement, of the type described in (1), in a group of Alorese L1 speakers and a group of Alorese L2 speakers. The Li sample consists of six female speakers, with ages ranging from 27 to 64 years, recorded in the villages of Alor Besar, Alor Kecil, and Dulolong. The L2 sample consists of 12 female speakers, with ages ranging from 25 to 46 years, recorded in the villages of Alor Besar, Alor Kecil, and Dulolong. The L2 speakers all have Adang as their L1, a language that is genealogically unrelated to Alorese, and has no subject agreement prefixes. ${ }^{5}$ The L2 speakers originated from the Adang speaking villages of Oamate, Aimoli, Ampera, and Bampalola, on Alor. They each learned Alorese in early adulthood, after marrying Alorese men. The length of residence in the Alorese villages and the consequent length of bilingualism varies from seven months to 27 years.

Each speaker performed four production tasks: (i) a free narrative (a fairytale or a personal experience); (ii) the Frog Story; (iii) the Surrey elicitation list (42 video clips); ${ }^{6}$ (iv) the Event and Position elicitation list (46 video clips). ${ }^{7}$ The free narrative and the description of the Frog Story elicit (semi-) free speech, while the two elicitation lists constrain the speaker to tell what she sees in the video clips. The video clips depict human characters performing various actions (e.g. washing dishes, cutting carrots, eating a banana), or depict objects (e.g. a house burning, a ball under a chair, a coconut palm blowing in the wind).

In order to investigate the use of agreement prefixes in L1 and L2 speakers, I examined all inflected verbs, and in each case, I coded whether the inflected verb was appropriate, given the overt (or understood) subject. Accurate agreement was labeled 'correct match' (example 2), inaccurate agreement (for instance a third person singular subject followed by a verb inflected for second person singular) was labeled 'agreement mismatch' (example 3), while a few cases were labeled 'ambiguous match' (example 4). The ambiguous matches

5 In Adang, it is the object that is prefixed to the verb (Haan, 2001: 46).

6 For a complete description of the video clips in the Surrey list see Fedden and Brown (2014: 447-451).

7 The Event and Position list is an elicitation list compiled by Hanna Fricke and Francesca Moro in the Nwo Vici Grant Research Project Reconstructing the past through languages of the present: The Lesser Sunda Islands (2014-2019). The list contains a selection of video clips and pictures developed by the Language and Cognition Department of the Max Planck Institute for Psycholinguistics (see http://fieldmanuals.mpi.nl/). It includes stimuli to elicit spatial relations, placement events, cut and break events and reciprocals. The list contains eight additional video clips shot by the authors to elicit give events. 
include those cases where the subject is absent, it is not understood from the context, or it can have a singular or plural reading. In (4) the noun tapo 'coconut' could mean both coconut palm (singular) or coconut fruits (plural), but it is not clear whether it is the coconut palm that is swinging, or the coconut fruits hanging from it.

(2) Correct match:

$\begin{array}{llllll}\text { Ina } & \text { kafae } & \text { kali } & n \text {-ate } & \text { bunga } & \text { mene } \\ \text { mother } & \text { girl } & \text { DEM.DIST } & \text { 3sG-carry } & \text { flower } & \text { come }\end{array}$

'That young woman brings some flowers.' (L1 speaker)

(3) Agreement mismatch:

\begin{tabular}{|c|c|c|c|}
\hline $\begin{array}{l}\text { Ina } \\
\text { mother }\end{array}$ & $\begin{array}{l}\text { kafae } \\
\text { girl }\end{array}$ & $\begin{array}{l}\text { m-ate } \\
\text { 2SG/1PL.EXCL/2PL-carry }\end{array}$ & $\begin{array}{l}\text { bunga } \\
\text { flower }\end{array}$ \\
\hline your & man & ngs some flowers.' (L2 spe & \\
\hline
\end{tabular}

(4) Ambiguous match:

$\begin{array}{lllllll}\text { Angi } & \text { te } & \text { pui } & \text { tapo } & \text { te } & \text { lalu } & \text { tapo } \\ \text { wind } & \text { DEM.MED } & \text { blow } & \text { coconut } & \text { DEM.MED } & \text { then(MLY) } & \text { coconut } \\ \text { te } & \text { apa } & \text { ha } & \text { ojang } & \text { r-ei } & \text { beta } & \text { r-ei... } \\ \text { DEM.MED } & \text { what(MLY) } & \text { DEM.PROX } & \text { sway } & \text { 3PL-go } & \text { arrive } & \text { 3PL-go }\end{array}$

'The wind blows the coconut(s) (tree?), what, (it/they) sway back and forth...'

(L2 speaker)

After coding each inflected verb as correct, mismatch or ambiguous, I analyzed the proportion of mismatched prefix and subject in the L1 and in the L2 groups. Subsequently, I analyzed the proportion of mismatches into three sub-groups of L2 speakers, divided according to length of exposure: the first with a length of exposure (LOE) to Alorese of 17-27 years; the second group with a LOE of five to eight years; the third group with a LOE of seven months to two years. Finally, I investigated the frequency of mismatches and the incidence of mismatches for each specific verb. The results are presented in the next section. While the small sample size does not allow for robust statistical analysis, a qualitative observation of the results shows an interesting pattern.

\subsection{Results}

A total of 659 inflected verbs are attested: 315 in the L1 speaker dataset and 344 in the L2 speaker dataset. The data are summarized in Table 3.

Agreement restructuring seems to be present in both L1 and L2 speakers, however the variation is more pronounced in the case of L2 speakers (27.3\%). 
TABLE 3 Inflected verbs in Alorese L1 and L2 speakers

\begin{tabular}{llrrr}
\hline & \multicolumn{2}{l}{ L1 speakers } & \multicolumn{2}{l}{ L2 speakers } \\
\hline Correct match & 307 & \multicolumn{2}{l}{243} & \\
Agreement mismatch & 7 & $97.4 \%$ & & $70.6 \%$ \\
Ambiguous match & 1 & $2.2 \%$ & & $27 \cdot 3 \%$ \\
Total inflected verbs & 315 & & 744 & \\
\hline
\end{tabular}

There is a statistically significant difference between the two groups using the non-parametric Mann-Whitney U test $(U=72.0, p<001$, two tailed $) .{ }^{8}$

Table 4 shows the variation in the three subgroups of L2 speakers. The proportion of mismatches in Group 1 (LOE: 17 to 27 years) and Group 2 (LOE: five to eight years) is almost identical, while it is higher in Group 3 (LOE: seven months to two years). Although this data should be taken with caution due to the small sample size, it seems that the individual proportion of mismatches tends to stabilize at around $20 \%$ from five years of exposure onward (and possibly from earlier).

The analysis of the variation in the use of the prefixes reveals that the inaccurate production of agreement morphology is not random, but it follows the same pattern in both L1 and L2 speakers. In the L1 group, the 3P L prefix $r$-is used with other subjects $5 / 7$ times, and the homophonous prefix $m$ - (2SG/2PL/1PL. EXCL.) is used the other two times, meaning that $r$-and $m$-occur where other (correct) prefixes would be expected. The L2 speakers follow a very similar pattern, the 3PL prefix $r$ - is used with other subjects $45 / 94$ times (47.8\%), followed by $m$ - (2SG/2PL/1PL.EXCL.), which is used 41/94 times (43.6\%). Therefore, together the 3PL prefix $r$ - and the homophonous prefix $m$ - account for approximately $91 \%$ of all inaccurate agreement in L2 speakers. These data are summarized in Table 5 and examples are presented below.

Two examples of mismatches in L1 speakers are given in (5) and (6). In (5) the verb $r-e i^{\prime} 3 \mathrm{PL}$-go' is inflected for third person plural, despite the subject being a third singular.

8 Following Field (2005: 522), I used the nonparametric Mann-Whitney U test because there are two conditions (agreement match and agreement mismatch) and different subjects in each condition, and the data are not normally distributed. 
TABLE 4 Agreement mismatches in three subgroups of Alorese L2 speakers

\begin{tabular}{|c|c|c|c|}
\hline L2 speaker & Group 1 (LOE: 17-27 years) & Tokens & $\%$ \\
\hline Speaker 1 & bilingual Adang-Alor (27 years) & $4 / 30$ & $13 \%$ \\
\hline Speaker 2 & bilingual Adang-Alor (20 years) & $14 / 41$ & $34 \%$ \\
\hline Speaker 3 & bilingual Adang-Alor (19 years) & $7 / 34$ & $21 \%$ \\
\hline Speaker 4 & bilingual Adang-Alor (1 7 years) & $5 / 20$ & $25 \%$ \\
\hline \multirow[t]{2}{*}{ Group average } & & & $24 \%$ \\
\hline & Group 2 (LOE: $5^{-8}$ years) & & \\
\hline Speaker 5 & bilingual Adang-Alor (8 years) & $3 / 22$ & $14 \%$ \\
\hline Speaker 6 & bilingual Adang-Alor (6 years) & $2 / 30$ & $7 \%$ \\
\hline Speaker 7 & bilingual Adang-Alor (6 years) & $16 / 56$ & $32 \%$ \\
\hline Speaker 8 & bilingual Adang-Alor ( 5 years) & $11 / 34$ & $32 \%$ \\
\hline Speaker 9 & bilingual Adang-Alor (5 years) & $9 / 41$ & $22 \%$ \\
\hline \multirow[t]{2}{*}{ Group average } & & & $23 \%$ \\
\hline & Group 3 (LOE: 7 months- 2 years) & & \\
\hline Speaker 10 & bilingual Adang-Alor (2 year) & $3 / 9$ & $33 \%$ \\
\hline Speaker 11 & bilingual Adang-Alor (1 year) & $13 / 13$ & $100 \%$ \\
\hline Speaker 12 & bilingual Adang-Alor (7 months) & $5 / 14$ & $36 \%$ \\
\hline Group average & & & $58 \%$ \\
\hline
\end{tabular}

TABLE 5 The prefix mismatch column reports the prefixes that were used by L1 and L2 speakers instead of another (correct) prefix

\begin{tabular}{llll}
\hline L1 speakers & Prefix mismatch & Tokens & $\%$ \\
\hline & $r$-'3PL' & $5 / 7$ & $71.4 \%$ \\
& $m$-'2SG/2 PL/1 PL.EXCL.' & $2 / 7$ & $28.5 \%$ \\
\hline \multirow{2}{*}{ L2 speakers } & Prefix mismatch & Tokens & $\%$ \\
\hline & $r$-'3PL' & $45 / 94$ & $47.8 \%$ \\
& $m$-'2SG/2PL/1 PL.EXCL.' & $41 / 94$ & $43.6 \%$ \\
& $n$-'3SG' & $6 / 94$ & $6.3 \%$ \\
& $k$-'1SG' & $2 / 94$ & $2.1 \%$
\end{tabular}




\section{(5) L1 SPEAKER:}

$\begin{array}{llllll}\text { Beka te } & \text { goka } & \text { r-ei } & \text { bana } & \text { onong } & \text { mung... } \\ \text { child DEM.MED fall } & \text { 3PL-go } & \text { forest } & \text { inside } & \text { SEQ } \\ \text { 'The child falls into the forest and...' } & & & \end{array}$

In (6) the verb $m$-ate 'bring' is inflected for $2 \mathrm{SG} / 2 \mathrm{PL} / 1 \mathrm{PL}$.EXCL, despite the subject being a third person singular.

(6) L1 SPEAKER:

$\begin{array}{lllll}\text { Gambe tou ha } & \text { m-ate } & \text { peda } & \text { mene } \\ \text { old.man one DEM.PROX } & \text { 2SG/2PL/1 PL.EXCL-carry } & \text { machete come } \\ \text { 'A man brings a machete.' } & & \end{array}$

L2 speakers also extend the use of the 3PL prefix $r$-and the homophonous $m$-, following the same pattern of L1 speakers, as shown in examples (7)-(9). In (7)-(8) the verbs host the 3 PL prefix $r$-, despite the subject being a third person singular. In (9) the verb is inflected for 2SG/2 PL/1PL.EXCL, but the subject is a third person singular.

(7) L2 SPEAKER:

Aho te palae palae palae r-ei oro sampe bana onong dog DEM.MED run run run 3 PL-go LOC until(MLY) forest inside 'The dog runs, runs, runs into the forest.'

(8) L2 SPEAKER:

Kafae te r-ate kajo tou te

girl DEM.MED 3PL-carry wood one DEM.MED

'The woman brings a stick.'

(9) L2 SPEAKER:

Gambe tou sapada dei mu old.man one 2SG/2PL/1PL.EXCL-carry machete upward SEQ 'A man brings a machete and...'

Additionally, the L2 dataset contains instances of overextension of the $3 \mathrm{SG}$ prefix $n$ - and of the 1SG prefix $k$-. In (10) the verb $n$-ei ' 3 SG-go' hosts the $3 \mathrm{sG}$ prefix $n$-, despite the subject being third person plural; in (11) the verb-kei '1SGgo' is inflected for $1 \mathrm{SG}$, but the subject is third person singular.

(10) L2 SPEAKER:

$\mathrm{Fe} \quad n$-ei nangge

3PL 3 SG-go swim

'They go swimming.' 
(11) L2 SPEAKER:

$\begin{array}{lllllll}A & \text { tou } & \text { te } & \text { palae } & \text { daka } & k-e i & t e \\ \text { person } & \text { one } & \text { DEM.MED } & \text { run } & \text { upward } & \text { 1SG-go } & \text { DEM.MED }\end{array}$

'A person runs going upward.

TABLE 6 Inaccurate verb forms among Alorese L2 speakers

\begin{tabular}{|c|c|c|c|c|}
\hline Verb & Meaning & Inaccurate verb form & Tokens & $\%$ \\
\hline \multirow[t]{2}{*}{-ate } & 'to carry' & m-ate & $11 / 17$ & $64 \%$ \\
\hline & & r-ate & $6 / 17$ & $35 \%$ \\
\hline \multirow[t]{3}{*}{-enung } & 'to drink' & m-enung & $8 / 13$ & $61 \%$ \\
\hline & & r-enung & $3 / 13$ & $23 \%$ \\
\hline & & n-enung & $2 / 13$ & $15 \%$ \\
\hline \multirow[t]{2}{*}{$-a n g$} & 'to eat' & $r-a k a$ & $13 / 15$ & $76 \%$ \\
\hline & & g-ang & $2 / 15$ & $13 \%$ \\
\hline \multirow[t]{4}{*}{$-e i$} & 'to go' & $r-e i$ & $23 / 46$ & $50 \%$ \\
\hline & & $m-e i$ & $20 / 46$ & $43 \%$ \\
\hline & & $n-e i$ & $1 / 46$ & $2 \%$ \\
\hline & & $k-e i$ & $2 / 46$ & $4 \%$ \\
\hline
\end{tabular}

The quantitative and qualitative data show that the $3^{\mathrm{PL}}$ prefix $r$ - and the homophonous 2SG/2PL/1PL.EXCL prefix $m$ - occur with other subjects and replace the expected prefixes. Although these two prefixes seem to be in competition, their selection is, at least partially, lexically driven. As shown in Table 6, for the verbs -ate 'to carry' and -enung 'to drink', the L2 speakers prefer the form with the prefix $m$-. For instance, the verb 'to carry' tends to occur in the form mate, regardless of the subject. For the verb 'to eat', L2 speakers prefer the form hosting the prefix $r$-, the suppletive form raka '. The verb -ei 'to go' does not show a clear preference, the forms rei and mei are used equally often.

To summarize, Alorese L2 speakers display considerable variation in the use agreement prefixes, despite having been immersed in a L2 speaking environment for more than five years. Following a pattern also observed among L1 speakers, L2 speakers extend the use of the homophonous prefix $m$ - and of the $3^{\text {PL }}$ prefix $r$ - to replace the expected prefixes. The choice between the prefix $m$ - or the prefix $r$-is lexically driven. 


\subsection{Discussion}

The subject prefixes are the last vestige of Alorese productive inflectional morphology. They have probably resisted so long because they occur on eight highfrequency vowel-initial verbs. Alorese syllable structure strongly disprefers vowel initial verbs: in the dataset used for the present study only five verbs out of $223(2.2 \%)$ begin with a vowel. Phonotactic restrictions and high frequency have arguably helped the preservation of this type of verbal agreement over the centuries and constrained omission. Another fact that might have contributed to the preservation of these prefixes is that the L1 of adult learners also has verb agreement prefixes (although in Alor-Pantar languages the prefixes usually index the $\mathrm{P}$ argument and not $\mathrm{A}$ or $\mathrm{S}$, see the grammatical descriptions in Schapper, 2014). Alorese verb prefixes, however, are not immune to change, as witnessed by the variation found among L2 speakers. This variation suggests that L2 speakers are restructuring the Alorese agreement system in order to reduce its complexity.

The type of variation found among Alorese L2 speakers consists in the substitution of one prefix in place of another (expected) prefix. In order words, L2 speakers extend the use of one prefix to the whole paradigm. The prefixes that appear to be the preferred default agreement option are $\mathrm{m}$ - and $r$-. I hypothesize here that since there are three homophonous $m$ - prefixes indexing different subjects (2SG, 1PL.EXCL and 2PL), L2 speakers may perceive this form as being underspecified for person and number and therefore, they use it as default agreement and generalize it to other subjects. Furthermore, the fact that there are three homophonous $m$ - makes this form quite frequent in the language. For the 3PL prefix $r$-, there is evidence that the third person plural is used for impersonals. The noun ata 'person' functions as a kind of impersonal pronoun and triggers the 3 PL possessive form, as illustrated in the following sentence, where the informant describes a young man who sits leaning against someone's wall (ata r-eing tembok 'someone 3PL-POss wall'). ${ }^{9}$ Thus, the use of the 3PL prefix $r$-for impersonal may account for the fact that this prefix has become semantically the default option in the repertoire of some L2 speakers.

The fact that the generalization of the prefix $r$-and $m$-is attested also in L1 speakers, although to a lesser extent (only seven tokens), may indicate that $\mathrm{L} 1$ speakers are affected by the same process of language change as L2 speakers. Although the data are too scarce to draw a solid conclusion, this may be an

9 The possessive linker is related to the possessive verb -(e)ing 'have', which occurs either in the third person singular form $n$-eing ' 3 SG-POSs' or in the third person plural form $r$-eing '3PL-POss' (see Klamer, 2011: 53). 
indication that the restructured variety of L2 speakers has already affected the language of L1 speakers and this variation may indeed become a fully-fledged change. If the generalization of these prefixes stabilizes, the forms $m$-ate 'to carry', m-enung 'to drink', m-ei or $r$-ei 'to come' and $r$-aka 'to eat' might eventually fossilize and become invariant forms. Unfortunately, it is not possible to test this prediction by comparing Alorese to Lamaholot. As previously noted, Lamaholot has a set of approximately 20 verbs hosting an A prefix (Nishiyama and Kelen, 2007:32), while in Alorese the set is only eight. The 12 verbs that inflect in Lamaholot, but not in Alorese, either do not show any correspondence between the two languages, or they are absent from my dataset. For instance, the verb 'to hunt' is -iu (inflected) in Lamaholot, but kori (not inflected) in Alorese, the verb 'to wait' is - awan (inflected) in Lamaholot, but baing (not inflected) in Alorese, the verb 'to stay' is - awa (inflected) in Lamaholot, but tobo (not inflected) in Alorese. Thus, it is important to point out that the mechanism operating at present (generalization of one prefix) might not have been operative in the past and that Alorese might have lost some of the inflected verbs, not by fossilizing a given prefix, but by innovating new lexical items.

In summary, the present case study has shown that the last vestige of productive inflectional morphology in Alorese is vulnerable to change and is subject to ongoing simplification. In order to simplify the system, L2 speakers do not omit the subject prefixes, but instead they extend one prefix to the entire paradigm to comply with Alorese syllable structure rules. L2 speakers tend to

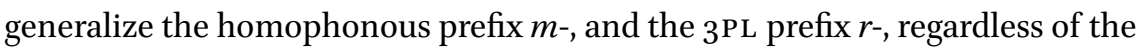
subject. The next section discusses the socio-historical factors that lead to this simplification.

4 Theoretical Models of Linguistic Change

This section discusses two models of linguistic change that place special emphasis on simplification and are, therefore, extremely relevant for the present study. The models of Kusters (2003) and Trudgill (2011) individuate a number of social factors as determinant of linguistic change and show that certain linguistic features are more commonly associated with certain types of societies.

Kusters' (2003: 41-45) proposes a model involving two communities: Type 1 and Type 2 communities. Type 1 communities are relatively small and share a common background as people tend to know each other. Usually outsiders not raised in the community do not learn the language and the number of L1 speakers far outnumbers the number of L2 speakers. Type 2 communities are generally large and their members do not share much background knowledge. 
Most of the members know other languages as well, and therefore the common language is mostly used for negotiating and exchanging practical information. Since the language mainly serves for information transmission, Type 2 communities tend to favor hearer comprehension, meaning that "the highest amount of information is transmitted to a hearer with the least effort and as clearly as possible" (Kusters, 2003: 41). In Type 2 communities L2 speakers form the larger segment of the population. This model is better characterized as a continuum, whereby Type 1 and Type 2 communities are prototypes falling at the ends of the continuum.

Languages of Type 1 communities tend to be morphologically more complex than languages of Type 2 communities. However, when a speech community changes from Type 1 to Type 2 , its language simplifies and the "simplicity of adult L2 language consists, among other things, in the lack of inflectional morphology" (Kusters, 2003: 49). Kusters shows that the loss of inflectional categories due to L2 learning is attested in four groups of languages, namely Quechua, Swahili, Arabic and Scandinavian. For instance, within the Scandinavian family Icelandic (the language within Scandinavia spoken by the a community most like Type 1) has retained, for the greatest part, the inflectional system of Old Norse, while Norwegian has lost all inflectional categories (except tense) due to contact with traders speaking Low German. The simplification process from Old Norse ( $13^{\text {th }}$ century) to Norwegian took place over 700 years.

Trudgill's (2011) model takes into account five social factors that influence the rate and type of linguistic change: contact, size, social networks, stability and the amount of communally shared information. Since stability relates more to the rate of change than the type of change and communally shared information correlates with size, Trudgill (2011: 147) operationalizes the remaining three factors in the matrix presented in Table 7.

Simplification occurs in communities characterized by high levels of adult language contact, large size and loose networks (prototypically Type 6). For instance, simplification occurred in English as a result of the Anglo-Saxon invasion of Britain and the consequent contact between speakers of Old English

TABLE 7 Six types of societies (Trudgill 2011: 147)

\begin{tabular}{lllllll}
\hline & $\mathbf{1}$ & $\mathbf{2}$ & $\mathbf{3}$ & $\mathbf{4}$ & $\mathbf{5}$ & $\mathbf{6}$ \\
\hline Size & small & small & small & small & large & large \\
Network & tight & tight & loose & loose & loose & loose \\
Contact & low & high & low & high & low & high \\
\hline
\end{tabular}


and native Britons who acquired Old English as a L2 (Trudgill, 2011: 50-55). The simplified version of English without, for example, case and gender agreement on adjectives, eventually became the dominant variety (Trudgill, 2011: 55). Interestingly, even the last vestige of English agreement morphology, the third person singular -s, has disappeared in the East Anglian dialect of Norwich (due to contact with Dutch and French speakers in the $16^{\text {th }}$ and $17^{\text {th }}$ centuries, see Trudgill, 1997), and in a number of more recent contact varieties, such as Singaporean English (Kortmann and Schneider, 2004-7).

If social factors, such as adult language contact, provide one explanation as to why languages simplify, simplification mechanisms can explain how this comes about. According to Trudgill (2011: 22, 62), the following mechanisms are responsible for simplification: increase in morphological transparency, regularization of irregularities, reduction of paradigmatic redundancy (loss of morphological categories), and reduction in syntagmatic redundancy (loss of redundant agreement). ${ }^{10}$ The disappearance of $3 \mathrm{SG}-s$ in some contact varieties of English is one example of loss of syntagmatic redundancy.

To sum up, Kusters (2003) and Trudgill (2011) models demonstrate the link between levels of linguistic simplicity and type of speech community. Reduction or even loss of morphological categories and grammatical agreement are more likely to occur in speech communities characterized by large amounts of adult language contact where L2 speakers form the larger segment of the population. The next section shows that Alorese is such a type of community where we expect, and actually find, considerable simplification.

This section presents past (section 5.1) and contemporary data (section 5.2) on the interaction between the coastal Alorese speaking community and the inland Adang speaking community on the peninsula Alor. The historical data are largely based on the work of the historical-anthropologist Emilie Wellfelt (2016) and the references cited therein. The present data come from Wellfelt

10 These mechanisms roughly correspond to the three simplification principles of Kusters (2003: 21-33): Economy, Transparency and Isomorphy. Economy leads to a reduction in the number of categories in inflectional morphology (similar to reduction of paradigmatic redundancy); Transparency leads to a one-to-one relationship between form and meaning (similar to the increase in morphological transparency); and Isomorphy leads to a semantically based order of morphemes reflecting the relevance of morphological categories to the stem. 
(2007) and my own fieldwork notes collected in the period May-June 2016. The evidence shows that contact has been, and still is, relatively intense, and therefore the Alorese are characterized as Type 2-like community (see section 5.3).

\subsection{Historical Evidence on the Interaction between the Alorese and the Adang}

We know from historical records that the Alorese arrived on Pantar from the west (from Flores and its offshore islands) in the first half of $14^{\text {th }}$ century (Klamer, 2011, 2012; Wellfelt, 2016). In the $16^{\text {th }}$ century, some of them moved to the peninsula of Alor and settled in the three coastal villages of Alor Besar, Alor Kecil and Dulolong (Wellfelt, 2016: 273). On the peninsula of Alor, the Alorese came into contact with the Adang, although the two groups occupied different niches: the Alorese are coastal, sea-oriented, Muslim people, while the Adang live in the interior, are land-oriented and are Christians or animists. Wellfelt (2016: 232) reports that the contact between the coastal (Austronesian) Alorese and the inland (Papuan) Adang has been so close, that the Adang have actually become culturally Austronesian; "a simple explanation for the Austronesian feeling in Adang society is the close interaction with the only Austronesian language in Alor, Alorese".11 There are at least four reasons supporting close contact: i) exogamy, ii) trade, iii) political alliances and iv) administrative duties during European colonialism. I will explain each of them here, below.

Traditionally, the Alorese exchanged women with the neighboring exogamous Adang community. Exogamy was a necessity, because the Alorese community only counted small settlements of about 200-300 people (Anonymous, 1914: 89-9o). In the patrilineal Adang and Alorese societies, a woman generally moves to the husband's village (cf. also DuBois, 1944: 85). Thus, since the $16^{\text {th }}$ century there must have been a continuous and considerable number of Adang women who married into Alorese families and learned Alorese as an L2.

Besides exchanging women, the Alorese and the Adang also exchanged goods. The Alorese offered coastal products, woven cloth and coffee, and in return they obtained inland products from farming or the forest (Wellfelt, 2007: 6, Klamer, 2011: 9). The Alorese were also involved in a Chinese-Muslim trade network bringing artifacts and slaves to Alor. The existence of, for instance, Chinese porcelain plates in the Adang oral histories and royal houses indicates that the Adang must have obtained these goods through the coastal Alorese (Wellfelt, 2016: 230, 250). Since the Alorese acted as intermediaries between

11 A similar case of cultural influence is reported by McWilliam (2007), who observes that the Fataluku (Papuan) society in East Timor exhibits many Austronesian cultural traits suggesting a long period of engagement and accommodation to Austronesian communities. 
the inland Adang population and the foreign merchants, it is likely that the language used for bartering was Alorese.

Further evidence for the close interaction between the Alorese and the Adang come from indigenous histories and shared traditions. Both Adang and Alorese stories tell about an Adang man and an Alorese woman who founded the first Alorese village, Alor Besar. This story is narrated in a poem that, quite symbolically, has the first verse in Adang and the second verse in Alorese (Wellfelt, 2007: 246). Additionally, the Alorese and the Adang are united since at least the $17^{\text {th }}$ century, in the so called '10-3-7'alliance, representing a league of ten Adang villages, three Alorese villages and seven villages on the island of Pura. ${ }^{12}$ Soon after this alliance was formed, the ruler of the Adang village O'a ceded power to the king of Alor Besar, due to the increase in seaborne trade (Wellfelt, 2016: 301). This alliance functioned as a peace-keeping factor and forged social relations, which still manifest today in yearly harvesting rituals (Wellfelt, 2007: 237). Every year, after the rice harvest, the king's house in Alor Besar hosts the ceremony Makan baru to which all the members of the '10-3-7'alliance are invited.

Finally, there is evidence that the Alorese rulers acted as intermediaries between the inland Adang population and the colonial governments. The ruler of Alor Besar was first officially acknowledged in $1813-1814$ by the Portuguese and again in the early 190o's by the Dutch (Wellfelt, 2016: 279, 283). Stokhof (1984: 111) reports that "[...] the mountain dwellers did not view them [coastal rulers] as their leaders, but at least accepted them as intermediaries in their trading contacts and as interpreters between themselves and the Dutch officials". According to DuBois (1944: 16), the Dutch granted control over the interiors to coastal rulers, because they could communicate with the inland population, as Malay was not yet widely known in the area. Although Stokhof and DuBois do not specifically refer to the Adang, it is plausible that the Alorese coastal rulers were intermediaries for them as well.

To conclude, the coastal Alorese and the Adang interacted in a number of ways: they exchanged women and goods; they made alliances, handed over political power to each other and created shared stories and traditions. Considering their role as intermediaries with foreign traders and the colonial government, it is very likely that the language of the Alorese was learned by (at least) a part of the Adang population to carry out these interactions and thus functioned as a sort of lingua franca in the area. 


\subsection{Present Evidence on the Interaction between the Alorese and the Adang}

Nowadays Alorese and Adang speakers interact and cooperate quite intensively. Many Adang speakers have moved to the coast, and it is possible to find hamlets of Adang villages next to the Alorese speaking villages. As in other parts of Indonesia, they engage in collective work to prepare fields, construct houses, and build mosques and/or churches. Wellfelt (2007: 17) reports that in the Alor regency "it is regarded as compulsory (wajib), for a Christian to help their neighbors in building a mosque; likewise it is a duty, and an honor, for a Muslim to help a Christian community with church construction". Alorese and Adang speakers come together to celebrate religious and traditional festivals, such as the harvest feast Makan Baru (see section 5.1). Furthermore, they often meet in the markets that are held by the coast, which function as exchange points for coastal and inland products (Wellfelt, 2007: 6).

This information does tell us that Alorese and Adang are in contact with each other, but it says nothing about the language(s) they speak. Kusters (2003: 38) warns that it is very difficult to measure the proportion of L2 speakers in a given community because often "the available data are not precise enough, neither for the ratio of L1/L2 learners, nor for the first language of the L2 learners". In order to partially solve this problem, I visited the village office (kantor desa) of the three Alorese villages and of 11 Adang villages, and I asked the village chief (kepala desa) or his secretaries about the main language spoken in the village, about the number of speakers of other languages and about the market place. Additionally, I consulted the Buku Induk Penduduk (BIP), which is the census book issued every few years by the Indonesian government.

The total number of inhabitants in the three Alorese speaking villages is 5,084. The data about the three Alorese villages are summarized in Table 8. The number of inhabitants in the three Alroese villages $(5,084)$ roughly corresponds to the number of Alorese L1 speakers. I say roughly because there

TABLE 8 Number of inhabitants of the three Alorese speaking villages

\begin{tabular}{ll}
\hline Alorese speaking villages on Alor Island & Inhabitants \\
\hline Alor Besar (BIP 2014) & 1536 \\
Alor Kecil (BIP 2015) & 1749 \\
Dulolong (BIP 2015) & 1799 \\
Total & 5084 \\
\hline
\end{tabular}


are also L2 speakers of Alorese living in the villages. This number, however, is not very high. The secretary of Alor Kecil reports of 22 women coming from outside ( 13 from the mountains who are Adang speakers and nine from other areas of Indonesia such as Flores, Macassar etc.).

There are 17 Adang villages in the peninsula Alor. It was only possible to gather data in 11 of them, so data from six villages are lacking (marked with a question mark in Table 9). The data about the Adang villages are summarized

TABLE 9 Number of inhabitants of the Adang speaking villages and estimated number of Alorese L2 speakers

Adang speaking

village

\begin{tabular}{lc}
\hline Alila (BIP 2013) & 822 \\
Kokar (BIP 2014) & 2621 \\
& \\
Alaang (BIP 2015) & 1197 \\
Aimoli (BIP 2014) & 1221 \\
Oamate (BIP 2016) & 827 \\
Ampera (BIP 2015) & 727 \\
& \\
Lewalu (BIP 2014) & 786 \\
& \\
Dulolong Barat (BIP 2015) & \multicolumn{1}{c}{832} \\
Teluk Kenari (BIP 2016) & 1013 \\
Kelurahan Kalabahi Barat & 3442 \\
(BIP 2015) & \\
Adang Buom (BIP 2015) & 1758 \\
Bampalola & $?$ \\
Hulnani & $?$ \\
Lefokisu & $?$ \\
Otvai & $?$ \\
Adang & $?$ \\
Alila Selatan & $?$ \\
Total & $? 5246$ \\
\end{tabular}

Alorese L2 speakers speakers

one hamlet, I estimate $50 \%$

411

$10 \%-25 \%$, I estimate

$45^{8}$

$17.5 \%$

$5 \%$ 59

$65 \%$ of half of the 396 inhabitants

$5 \%$ 41

almost all inhabitants, I $\quad 654$ estimate $90 \%$.

almost all inhabitants, I $\quad 707$ estimate $90 \%$.

almost all inhabitants, $90 \% \quad 748$

$20 \%$

202

$40 \%$

1376

10-20\%, I estimate $15 \% . \quad 263$

?

?

?

? ?

$?$ ?

? ?

? ? 
in Table 9. In each of the 11 villages that I surveyed, I asked how many people were able to speak Alorese as a second language. When I asked about how Adang people learned Alorese I obtained a very consistent answer, namely that they learnt it by spending time with Alorese speakers (pergaulan), or by going to the market in Alor Kecil, or at parties. Notably, the Alorese village of Alor Kecil hosts the biggest market in the area, every Tuesday and Friday. These answers are congruent with the interaction scenario discussed above.

The total number of inhabitants of the Adang villages is 15,246; of these about a third $(5,315)$ speak Alorese as an L2. The number of L2 speakers is either based on the percentage provided by the village chief or it is estimated on the basis of other information. For instance, the village Alila is formed by two hamlets (dusun). The village chief reported that inhabitants of one hamlet could also speak Alorese, so I estimated that roughly $50 \%$ of Alila inhabitants could speak Alorese as an L2.

Interestingly, the data from Table 8 and Table 9 show that the number of Alorese L2 speakers $(5,315)$ is higher than the number of Alorese L1 speakers $(5,084)$. A possible over-estimation of L2 speakers is evened out by the missing data for Alorese L2 speakers from the six Adang villages, which was unavailable to me. If, on the contrary, the number of L2 speakers is under-estimated, a higher number will only strengthen the claim that Alorese L2 speakers outnumber L1 speakers.

To summarize, considering the geographical proximity of Alorese and Adang villages presently, and the many opportunities to come together and interact (markets, feasts, building churches and mosques), it is reasonable to assume that the Alorese and the Adang needed a language to communicate and that this language is (or has been until recently) Alorese. The situation is changing, because Indonesian and the local variety of Malay are slowly but surely replacing Alorese as a lingua franca in the region.

\subsection{Summary: Alorese, a Type-2-Like Community}

Given the amount of adult language contact, the Alorese community is characterized as a Type 2-like community in Kusters (2003) typology. We find a large amount of adult language contact, as the language is commonly acquired by Adang L1 speakers and it is (mostly) used for negotiating and exchanging practical information. In the past, the Alorese communities were smaller $(200-300$ individuals, Anonymous, 1914: 89-90), and with tighter networks, although contact with the Adang was already intense (see section 5.1). Both Trudgill and Kusters models predict that languages of Type 2 -like communities, such as the Alorese, undergo simplification (see section 4). This is exactly what we find (see section 3). 
This paper describes the contact-induced variation attested in Alorese by taking into account the sociolinguist setting in which Alorese is spoken. Historical, cultural and demographic data are used to classify the Alorese as a Type 2 community, where the Alorese language was learned by a large amount of L2 speakers. For about four centuries (from the $16^{\text {th }}$ to $20^{\text {th }}$ century), the Alorese and the Adang intermarried, bartered local products and foreign goods, created alliances, participated in harvesting feasts, and carried out political negotiations. In Type 2 communities, such as the Alorese, L1 speakers tend to accommodate and assimilate the speech of L2 speakers. For the sake of efficiency and ease of communication, Alorese L1 speakers adopted the simplified variety of L2 speakers, one without morphology, and passed it on to their children. Thus, there are reasons to believe that the simplified variety, which eventually became dominant, was not only used by Adang speakers, but also by the Alorese speakers themselves. One example comes from the synchronic data presented in the case study in section 3, where we observe that the generalization of the prefix $r$-and $m$-is also present in some L1 speakers. This may be an indication that the restructured variety of L2 speakers has been adopted by the L1 speakers and is becoming the norm.

Nowadays, Alorese is still learned by many Adang speakers as an L2, and some of them even use it to communicate to each other. When Adang women living in the Alorese villages interact, they use Adang only if there is no one else involved in the conversation; otherwise they speak Alorese. The use of Alorese among L2 speakers reinforces and accelerates linguistic change. This is known as the 'vicious circle of language change', where the linguistic input from other L2 speakers is taken as corroborating evidence by other bilinguals who, in turn, expose other speakers to the patterns of simplification, thus perpetuating the circle (Enfield, 2003: 366; Schmid, 2011: 170). In addition to this, it must be noted than in pre-literate societies, like the Alorese, linguistic normativity does not play an important role (see Backus and Spotti 2012, for a discussion on normativity and language change). It is, therefore, very likely that L2 speakers do not receive corrective feedback from L1 speakers when they deviate from the L1 norm. This may also explain why even speakers with a long exposure to Alorese (more than five years) still display considerable variation in their use of subject prefixes. After all, the goal for L2 speakers is to reach a level that is "good enough" for communication.

The study of agreement prefixes presented in section 3 addresses the issue of morphological stability in contact situations involving untutored L2 learning. Morphology and especially inflectional morphology, is not stable in 
contact situations involving adult L2 learning, because adult L2 acquisition is primarily driven by the principle of Economy, which demands that as few semantic categories as possible should be expressed morphologically (Kusters, 2003; Trudgill, 2011). Hence, inflectional morphology is the first aspect that tends to be simplified in L2 grammars. In light of this, it is not surprising that the way in which Alorese simplified was by losing its morphology. First, it reduced its paradigmatic redundancy (semantic categories of A and S) and today it is on its way to losing syntagmatic redundancy (subject agreement). The loss of the morphological categories $\mathrm{A} / \mathrm{S}$ is a change that has reached completion, whereas the variation in the use of subject prefixes is a case of ongoing simplification.

In section 3.3, I have discussed in more detail, the variation attested among L2 speakers. The way L2 speakers are restructuring the system is by extending one prefix to the entire paradigm to comply with syllable structure rules. The most common strategy is the generalization of the homophonous prefix $m$-, and of the 3PL prefix $r$-, regardless of the subject. The prefix $m$ - may be perceived by L2 speakers as being underspecified for person and number and therefore is suitable to be used as default agreement. If this ongoing change eventually reaches completion, and the verb forms such as mate 'to carry', or menung 'to drink', fossilize, then Alorese will have lost all its inflectional morphology and will become even simpler than it already is. However, it is important to point out that this simplification mechanism might not have been operative in the past, as there is no evidence of fossilized verbs with an $m$-or $r$ - prefix in Alorese when compared to Lamaholot. So, it is likely that different simplification mechanisms operate at different times.

To conclude, this paper has shown that Alorese has lost almost all its morphology due to adult language contact. The interactions between the Alorese (Austronesian) and the neighboring Adang (Papuan) have been and still are relatively intense, supporting a scenario typical of a Type 2 community, where L2 speakers form a large segment of the population. In other words, I believe that the simplification from Proto-Lamaholot to Alorese was fundamentally no different from the simplification from Old English and English, or from OldNorse to Norwegian, which all took place in Type 2-like communities across several centuries.

\section{$7 \quad$ Abbreviations}

The abbreviations used in this paper are: 1, 2, 3= first, second, third person, $\mathrm{A}=$ agent-like argument of transitive verb, $\mathrm{DEM}=$ demonstrative, $\mathrm{DIST}=$ distal, 
$\mathrm{EXCL}=$ exclusive, $\mathrm{INCL}=$ inclusive, $\mathrm{L} 2=$ second language, $\mathrm{MED}=$ medial, $\mathrm{MLY}=$ Malay, $\mathrm{PL}=$ plural, $\mathrm{PROX}=$ proximal, $\mathrm{S}=$ single argument of intransitive verb, $\mathrm{SEQ}=$ sequential, $\mathrm{SG}=$ singular.

\section{References}

Anonymous. 1914. De eilanden Alor en Pantar, Residentie Timor en Onderhoorigheden. Tijdschrift van het Koninklijk Nederlandsch Aardrijkskundig Genootschap 31: 70-102. Backus, Ad and Massimiliano Spotti. 2012. Normativity and change: introduction to the Special issue on Agency and power in multilingual discourse. Sociolinguistic Studies 6(02): $185^{-208 .}$

DuBois, Cora. 1944. The people of Alor: a social-psychological study of an East Indian island. Cambridge, MA: Harvard University Press.

Enfield, Nick. J. (2003). Linguistic epidemiology: Semantics and grammar of language contact in Mainland Southeast Asia. London: Routledge.

Fedden, Sebastian and Dunstan Brown. 2014. Participant marking: Corpus study and video elicitation. In Marian Klamer (ed.), The Alor-Pantar languages: History and typology, 413-56. Berlin: Language Science Press.

Fernandez, Inyo Yos. 1996. Relasi historis kekerabatan Bahasa Flores. Ende, Indonesia: Penerbit Nusa Indah.

Field, Andy. 2005. Discovering statistics using SPSS. London. England: SAGE.

Foley, William A. 1986. The Papuan languages of New Guinea. Cambridge, UK: Cambridge University Press

Fricke, Hanna. 2014. Topics in the grammar of Hewa: A variety of Sika in Eastern Indonesia. MA Thesis, Leiden University.

Haan, Johnson W. 2001. The Grammar of Adang: A Papuan Language Spoken in the Island of Alor, East Nusa Tenggara - Indonesia. PhD Dissertation, University of Sydney.

Holton, Gary, Marian Klamer, František Kratochvíl, Laura Robinson, Antoinette Schapper. 2012. The historical relation of the Papuan languages of Alor and Pantar. Oceanic Linguistics 51(1): 87-122.

Klamer, Marian. 2011. A short grammar of Alorese (Austronesian). Munich: Lincom Europe.

Klamer, Marian. 2012. Papuan-Austronesian language contact: Alorese from an areal perspective. In Marian Klamer and Nicholas Evans (eds.), Melanesian languages on the Edge of Asia: Challenges for the 21th Century, 72-108. Honolulu, HI: University of Hawai'i Press.

Klamer, Marian. To appear. From Lamaholot to Alorese: Morphological loss in adult language contact. In David Gil and Antoinette Schapper (eds.), Austronesian Undressed: How and why languages become isolating. Amsterdam: Benjamins. 
Kortmann, Bernd and Edgar W. Schneider (eds.). 2004-7. A Handbook of Varieties of English: A Multimedia Reference Tool. Berlin:Mouton de Gruyter. Available at http:// www.varieties.mouton-content.com/ (accessed March 23, 2017)

Kusters, Wouter. 2003. Linguistic complexity. PhD Dissertation, Utrecht: LOT.

Levinson, Stephen C. and Asifa Majid. 2017. L\&C Field Manuals and Stimulus Materials. Nijmegen: Max Planck Institute for Psycholinguistics. Available at http://fieldmanuals.mpi.nl/ (accessed March 31, 2017).

McWilliam, Andrew. 2007. Austronesians in linguistic disguise: Fataluku cultural fusion in East Timor. Journal of Southeast Asian Studies 38(2): 355-375.

Nagaya, Naonori. 2011. The Lamaholot language of eastern Indonesia. PhD dissertation, Rice University.

Nishyama, Kunio and Herman Kelen. 2007. A grammar of Lamaholot, Eastern Indonesia: The morphology and syntax of the Lewoingu dialect. Munich: Lincom Europa.

Samely, Ursula. 1991. Bahasa Kedang (Eastern Indonesia): Some aspects of its Grammar. Hamburg: Buske.

Schapper, Antoinette (ed).2014. The Papuan Languages of Timor, Alor and Pantar: Volume 1: Sketch Grammars. Berlin/Boston: Walter de Gruyter.

Schendl, Herbert. 2001. Historical Linguistics. Oxford: Oxford University Press.

Schmid, Monika. S. 2011. Contact x time: External factors and variability in L1 attrition. In Monika. S. Schmid and Wander Lowie (eds.), Modeling bilingualism: From structure to chaos. In honor of Kees de Bot, 155-176. Amsterdam and Philadelphia: John Benjamins.

Simons, Gary F. and Charles D. Fennig. 2017. Ethnologue: Languages of the World, Twentieth edition. Dallas, Texas: SIL International. Available at http://www.ethnologue. com (accessed March 31, 2017).

Stokhof, Willem. A. 1975. Preliminary Notes on the Alor and Pantar Languages: East Indonesia. Canberra: Pacific Linguistics.

Stokhof, Willem. A. 1984. Annotations to a text in the Abui language (Alor). Bijdragen tot de taal-, land-en volkenkunde 140(1):106-162.

Trudgill, Peter. 1997. Third-person singular zero: African-American English, east Anglian dialects and Spanish persecution in the Low Countries. Folia Linguistica Historica 31: 139-148.

Trudgill, Peter. 2011. Sociolinguistic typology: social determinants of linguistic complexity. Oxford: Oxford University Press.

Wellfelt, Emilie. 2007. Diversity \& Shared Identity. A case study of interreligious relations in Alor, Eastern Indonesia. MA Thesis, Göteborg University.

Wellfelt, Emilie. 2016. Historyscapes in Alor. Approaching indigenous histories in eastern Indonesia. PhD dissertation, Linnaeus University. 